\title{
Cambridge and Heidelberg compete for new European gene database
}

London \& Munich. Two of the world's oldest university towns are bidding to host Europe's main store of information about human and animal genes. The databank, to be known as the European Bioinformatics Institute (EBI), is likely to become a cornerstone of the biotechnology industry and will compete with the more advanced US GenBank.

Germany wants the EBI to go into a new 2,400 square metre building on the European Molecular Biology Laboratory (EMBL) site in Heidelberg. Details are being kept secret until next week's deadline for tender, although rumours suggest that the state of Baden-Württemberg would donate the land and the federal government would provide DM12 million (US\$7.5 million) in capital.

But British scientists have put together an $£ 8$ million (US\$12 million) proposal for the institute to be located close to Cambridge. Backed by the Medical Research Council (MRC) and the Wellcome Trust, which would each contribute half of the initial capital costs, the institute would be established on a 55-acre parkland site nine miles south of Cambridge.

At the moment, EMBL operates Europe's gene and protein databases (the European Nucleotide Sequence Database and SWISSPROT, which is run jointly with the University of Geneva) and several other specialist databases on a budget of DM5 million a year and a staff of 40 . The Commission of the European Communities (EC) has also donated a total of ECU2 million (US $\$ 2.6$ million) in the past four years.

The 13-year-old EMBL data library has outgrown its base, and EMBL has decided to move it to a separate institute that would include a research department. The department would keep the library's technology up to date and provide support and training for users.

EMBL estimates that EBI will cost more than DM12 million. Although a call for tenders was put out in December for the building and equipping of the institute as an EMBL outstation, a decision about running costs was deferred until next month's meeting of the EMBL council. Europe lags behind the US GenBank, which offers free service internationally, a more sophisticated computer system and an active research team. In addition, Europe wants its own database to protect itself if the US government ever begins charging for use of GenBank.

Member countries had only two months to submit a bid, a deadline favouring those already well along. Although Spain and
Sweden have expressed verbal interest, only Germany and Britain have developed specific proposals.

The site will be chosen on the basis of its access to expertise in molecular biology and computing and its links to fast electronic networks. Ideally, for administrative reasons, it should also be associated with a laboratory with the same international status as EMBL.

British officials point out that the Cambridge site offers direct access to the many molecular biologists working at both the university and the MRC's Laboratory of Molecular Biology (LMB), as well as the Agricultural Research Council's Institute of Animal Physiology and Genetics Research at Babraham. Those working on techniques for interpreting in-

formation about gene and protein structure from data stored in the database would have similar access to experts in computing.

"Cambridge has an enormous research community of exactly the type that we want the EBI to flourish in", says John Sulston of the LMB, who has recently been appointed director of the Sanger Centre, a new institution for genomic research. Cambridge also has excellent high-speed data links with the rest of the world. A 2-megabit link available through the JANET network is soon to be upgraded to a 34-megabit link through the new network SUPERJANET.

The estate on which the EBI and the Sanger Centre would be based, Hinxton Park, is being bought by the Wellcome Trust. At present it includes not only an eighteenth-century house, but also 4,000 square metres of laboratory space for scientists at the Sanger Centre to use while waiting for their own building to be completed. The initial capital costs, which would be shared by Wellcome and the MRC, include $£ 2$ million to transfer the existing databank from Heidelberg.

At a meeting in London last week, the proposal to locate the EBI in Cambridge received the support of both the Science and Engineering Research Council and the Agri- cultural and Food Research Council.

Germany's alternative bid to locate the EBI at Heidelberg offers its own advantages. The current data library would move only across the road to what is now a parking lot, and EMBL's status as an international laboratory would simplify administrative problems. The institute would also benefit

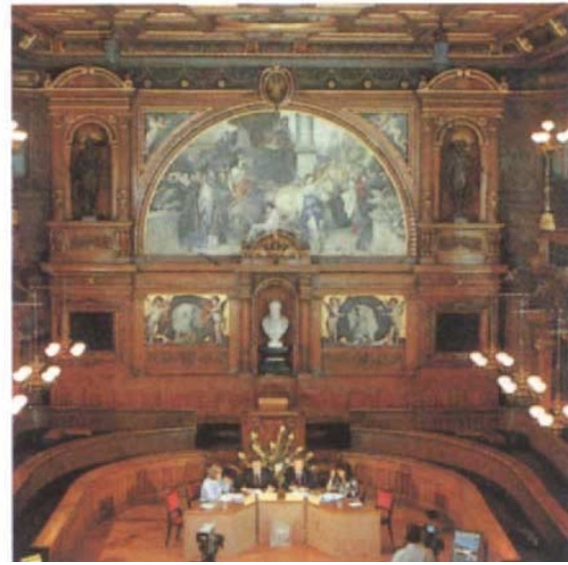

from the talent already assembled in Heidelberg.

Counting against it, however, are Germany's poor electronic datalinks with the rest of the world. Germany has always lagged behind other high-technology nations in electronic networks and, according to Graham Cameron, EBI project leader, this weakness has caused quite a few problems in the past couple of years. The immediate future offers the possibility of upgrading its current $64 \mathrm{~K}$ bit links to a 2 megabit commercial link - at a price. But anything faster lies far into the future.

The choice of a site and a decision on how to meet operating costs will be made at next month's EMBL council meeting. One option is to reject the concept of EBI as an EMBL outstation and instead set it up as an independent foundation.

David Dickson \& Alison Abbott 